ISSN 2080-1653

DO1 10.24917/20801653.314.8

\author{
JULIA KACZMAREK-KHUBNAIA \\ Uniwersytet im. Adama Mickiewicza, Poznań, Polska \\ Adam Mickiewicz University, Poznan, Poland
}

\title{
Powiązania gospodarcze państw postradzieckich na przykładzie bezpośrednich inwestycii zagranicznych
}

\section{Economic Links of the Post-Soviet Countries as Illustrated by Foreign Direct Investment}

\begin{abstract}
Streszczenie: Utworzenie Związku Radzieckiego, w ramach określonego założenia politycznego, wymagało od jego władz przeprowadzenia licznych reform politycznych i gospodarczych. Jednym z głównych celów jego powstania było stworzenie odseparowanego od innych krajów (w szczególności zachodnich), samowystarczalnego i zintegrowanego wewnętrznie tworu państwowego. Po upadku ZSRR byłe republiki związkowe odzyskały niepodległość. Transformacje systemowe umożliwiły im rozszerzenie kierunków handlu oraz przepływu środków finansowych w postaci nowych inwestycji o kraje spoza obszaru radzieckiego. Celem artykułu jest analiza powiązań gospodarczych występujących obecnie pomiędzy byłymi republikami Związku Radzieckiego przez pryzmat wielkości i struktury geograficznej (kierunków) przepływów bezpośrednich inwestycji zagranicznych. Porównanie w pracy wyników analizy danych z uwarunkowaniami historycznymi oraz aktualną sytuacją geopolityczną w regionie pozwoliło autorce odpowiedzieć na postawione we wstępie artykułu pytanie badawcze: „Czy obecnie można mówić o istotnej reorganizacji polityki gospodarczej, polegającej na rzeczywistym otwarciu państw postradzieckich na nowe rynki, czy ich dalszej integracji z krajami, których obszary znajdowały się w przeszłości za tzw. żelazną kurtyną?". Artykuł wzbogacono ponadto o krótki przegląd ustaleń terminologicznych.
\end{abstract}

\footnotetext{
Abstract: The creation of the Soviet Union (USSR), as the result of a specific political objective, required a large number of political and economic reforms. One of the main objectives was the establishment of a state that is isolated from other countries (particularly the western ones), independent, self-sufficient and internally integrated. After the dissolution of the USSR, the former Soviet republics became independent. Political transformations facilitated the development of a more dynamic international trade and opened new possibilities for foreign investments. The aim of this article is, through careful examination of the size and geographical structure (direction) of direct foreign investments, to analyse and explain specific economic links currently existing between the former Soviet republics. Comparing the results of the analysis with historical determinants and the geopolitical situation in the region has allowed the author to answer the initial question of the article: Can we really speak of a reorganisation of the political economy based on actual opening of the post-soviet countries to new markets? Or is it rather a matter of further integration with the countries that have been similarly situated behind the so called iron curtain? Additionally, the article contains a short review of used terminology.
} 
Słowa kluczowe: bezpośrednie inwestycje zagraniczne; globalizacja; powiązania gospodarcze; Związek Radziecki

Keywords: economic links; foreign direct investment; globalization; Soviet Union

Otrzymano: 31 grudnia 2016

Received: 31 December 2016

Zaakceptowano: 20 sierpnia 2017

Accepted: 20 August 2017

\section{Sugerowana cytacja / Suggested citation:}

Kaczmarek-Khubnaia, J. (2017). Powiązania gospodarcze państw postradzieckich na przykładzie bezpośrednich inwestycji zagranicznych. Prace Komisji Geografii Przemysłu Polskiego Towarzystwa Geograficznego, 31(4), 120-132. https://doi.org/10.24917/20801653.314.8

\section{WSTĘP}

Na kształt dzisiejszego świata, często określanego mianem globalnej wioski, w istotnym stopniu wpływają procesy globalizacji. Przemiany strukturalne gospodarek narodowych, w tym kolejne fazy ewoluującego kapitalizmu, liberalizacja polityki dotyczącej współpracy międzynarodowej (reformy gospodarcze) i otwarcie rynków bezpośrednio oddziałują na kształtowanie się współzależności i powiązań oraz pogłębianie relacji gospodarczych pomiędzy państwami. Kluczową rolę w powyższym procesie miały: rewolucja technologiczna, większa mobilność pieniądza oraz wzrost znaczenia wiedzy i innowacyjności (Przygodzki, 2007).

Analizując przejawy oraz charakter procesów globalizacji, należy odwołać się do ich wielowymiarowości oraz zakresu (pola) oddziaływania. W literaturze przedmiotu, oprócz odniesień do charakterystycznych dla integracji państw przemian społecznych i kulturowych, badacze odwołują się również do ich gospodarczego wymiaru, w tym także do pojęcia globalizacji działalności gospodarczej, w której istotną rolę pełni intensyfikacja powiązań inwestycyjnych (Zorska, 2000).

Biorąc pod uwagę geopolitykę oraz światowe tendencje przepływu kapitału i dóbr, kształtujące globalny rynek, między innymi utrzymującą się silną pozycję tzw. państw Triady $^{1}$, koniecznym wydaje się dokonanie analizy powiązań występujących pomiędzy byłymi członkami ZSRR, jednej z największych potęg gospodarczych XX wieku. Upadek Związku w latach dziewięćdziesiątych XX wieku zapoczątkował okres transformacji systemowych i diametralnie odmienił sytuację wchodzących w przeszłości w jego skład republik. Wkroczenie w nowy etap historii umożliwiło im dokonanie wcześniej niemożliwych zmian oraz zorientowanie swojej polityki na zachodnie standardy gospodarowania. Co ważne, możliwa stała się również reorientacja, wcześniej odgórnie narzucanych, kierunków rozwoju i integracji gospodarczej. Liczne bariery rozwojowe, w tym kryzysy gospodarcze, mnogość konfliktów zbrojnych na ich obszarach oraz niestabilność polityczna, z pewnością negatywnie wpływały na kształtowanie się nowej sieci ich powiązań ekonomicznych.

Celem artykułu jest analiza powiązań gospodarczych, które występują współcześnie, pomiędzy byłymi republikami związkowymi, przez pryzmat wielkości i struktury geograficznej (kierunków) przepływów bezpośrednich inwestycji zagranicznych (BIZ).

${ }^{1} \mathrm{~W}$ jej skład wchodzą trzy grupy państw: Ameryki Północnej (Stany Zjednoczone, Kanada), Europy Zachodniej (głównie członkowie Unii Europejskiej) i Azji Wschodniej (m.in.: Japonia, Singapur, Korea Południowa) (Zorska, 2000). 
Skonfrontowanie analizy danych statystycznych z kluczowymi uwarunkowaniami historycznymi (charakterystyką założeń politycznych i gospodarczych ZSRR) oraz obecną sytuacją geopolityczną $\mathrm{w}$ regionie pozwoliło odpowiedzieć na postawione przez autorkę pytanie badawcze: „Czy obecnie można mówić o istotnej reorganizacji polityki gospodarczej, polegającej na rzeczywistym otwarciu państw postradzieckich na nowe rynki, czy ich dalszej integracji z krajami, których obszary znajdowały się w przeszłości za tzw. żelazną kurtyną?".

W artykule odniesiono się do 2014 roku, aczkolwiek z powodu konieczności uwzględnienia najważniejszych uwarunkowań historycznych zakres czasowy pracy poszerzono o okres istnienia Związku Radzieckiego. Zakres przestrzenny pracy obejmuje wszystkie kraje będące byłymi republikami ZSRR, jednak z powodu braku części danych z analizy wyłączono na wstępie Uzbekistan, Tadżykistan i Turkmenistan.

Aby wykazać zróżnicowanie wielkości przepływów i kierunków powiązań, autorka zastosowała metody matematyczno-statystyczne, związane z obserwacją oraz przekształcaniem i analizą wybranych danych, i historyczno-opisową, odnoszącą się do badania uwarunkowań historycznych. W badaniu skorzystano z bazy danych Coordinated Direct Investment Survey (2016, 25 grudnia), opublikowanych na stronie internetowej Międzynarodowego Funduszu Walutowego (IMF).

\section{BEZPOŚREDNIE INWESTYCJE ZAGRANICZNE - USTALENIA TERMINOLOGICZNE}

Rozważania dotyczące powiązań gospodarczych, występujących pomiędzy państwami wchodzącymi w skład grupy postsowieckiej, należy rozpocząć od krótkiego przeglądu ustaleń terminologicznych dotyczących bezpośrednich inwestycji zagranicznych. B. Domański (2001) definiuje je jako „takie inwestycje, które mają na celu uzyskanie przez zagranicznego inwestora trwałego dochodu poprzez efektywny wpływ na decyzje miejscowego przedsiębiorstwa (Domański, 2001: 12).

I. Michałków (2003) tłumaczy powyższe pojęcie jako tzw. strumień kapitału, przy pomocy którego inwestor kontroluje przedsiębiorstwo powstałe za granicą.

Konferencja Narodów Zjednoczonych ds. Handlu i Rozwoju (UNCTAD) wspomina, iż ,jest to inwestycja przez przedsiębiorstwo lub osobę fizyczną jednego kraju (czyli przedsiębiorstwo matkę kraju pochodzenia BIZ) w przedsiębiorstwo innego kraju (zwane filią zagraniczną w kraju przyjmującym BIZ), podejmowana z zamiarem sprawowania długotrwałej kontroli pozwalającej zarządzać filią zagraniczną" (Olifirowicz, Wasilik-Dusińska, 2002: 13). Na uwagę zasługuje również, często przytaczana przez naukowców, definicja Organizacji Współpracy Gospodarczej i Rozwoju (OECD), podająca dwa główne warunki różnicujące BIZ od innych rodzajów inwestycji: po pierwsze inwestor sprawuje kontrolę nad minimum 10\% udziałów lub akcji, po drugie ma co do niego plany długofalowe. Podział ten pozwala między innymi na odróżnienie ich od inwestycji portfelowych (Olifirowicz, Wasilik-Dusińska, 2002).

Warto zauważyć, iż w większości przytoczonych powyżej definicji, zarówno autorstwa badaczy zajmujących się powyższą problematyką, jak i organizacji międzynarodowych, takich jak UNCTAD czy OECD, odwoływano się do kwestii kontroli oraz wpływu przedsiębiorstw matek na zagranicznych rynkach (w państwach goszczących inwestycje, lokalizacjach filii). 
A. Cieślik (2005) wprost wskazuje, iż w przypadku inwestycji tego typu działalność kontrolna często jest kwestią nadrzędną w stosunku do wymiaru ekonomicznego przedsięwzięcia. Temat BIZ jest więc istotny, szczególnie w odniesieniu do możliwości zarządczych, sprawowania szeroko pojętej kontroli oraz wpływu i znaczenie inwestycji w procesach integracji i dezintegracji.

Na procesy globalizacji znaczący wpływ mają - obok państw narodowych, kształtujących wewnętrzną politykę ekonomiczną, oraz międzynarodowych organizacji gospodarczych, takich jak UNCTAD czy Bank Światowy - korporacje transnarodowe, będące przejawem długofalowych procesów internacjonalizacji działalności gospodarczych (Zorska, 2007).

Bezpośrednie inwestycje zagraniczne mogą być zróżnicowane i przybierać różne formy. Środki finansowe napływają do nowych, lub powiększonych przedsiębiorstw (inwestycje od podstaw, greenfield) lub mają charakter przejęcia albo fuzji firm znajdujących się w kraju goszczącym inwestycje (filii) przez przedsiębiorstwo matkę (Cieślik, 2005).

\section{UWARUNKOWANIA HISTORYCZNE AKTUALNYCH POWIĄZAŃ GOSPODARCZYCH NA OBSZARZE POSTRADZIECKIM}

\section{Związek Radziecki jako projekt polityczny}

Utworzenie Związku Radzieckiego, w ramach wcześniej określonego projektu politycznego, wymagało od jego władz przeprowadzenia licznych reform oraz reorientacji polityki wewnętrznej i zagranicznej. Zdaniem socjalistów, Rosja carska była krajem opóźnionym gospodarczo, przepełnionym dysproporcjami ekonomicznymi oraz silnie uzależnionym od obcego kapitału (Ławriszczew, 1969; Maryański, 1987).

Wprowadzenie nowego systemu politycznego wiązało się z zastosowaniem w wysokim stopniu autarkicznego modelu gospodarki centralnie sterowanej, w którym jednym z głównych priorytetów było stworzenie warunków zapewniających pełną niezależność ekonomiczną kraju. Sukcesywnie wdrażano tzw. prawa ekonomiczne socjalizmu. Istotnymi elementami, stanowiącymi podstawę reform gospodarczych państwa, były jego powszechna industrializacja, w dużej mierze wspierana poprzez aktywizowanie tzw. wewnętrznych źródeł akumulacji, w pierwszym okresie istnienia państwa, przeprowadzana znacznym kosztem jakości życia jego mieszkańców, oraz mechanizacja i kolektywizacja rolnictwa. Zcentralizowana władza znacjonalizowała rynek. Politykę kraju ukierunkowano na szeroko pojętą rywalizację z innymi potęgami gospodarczymi (przede wszystkim ze Stanami Zjednoczonymi), zarówno na płaszczyźnie zbrojeń i wojskowości, jak nauki i postępu technologicznego oraz tempa rozwoju społeczno-ekonomicznego (Szeliga, 1967; Rychłowski, 1976).

Głównym celem państwa było więc stworzenie odseparowanego od innych krajów (szczególnie zachodnich), niezależnego, samowystarczającego i wewnętrznie zintegrowanego tworu państwowego.

Związek Radziecki, w ramach programowania rozwoju, stosował plany wieloletnie oraz rejonizację ekonomiczną. Państwo podzielono na 18 regionów ekonomicznych, w skład których wchodził cały obszar ZSRR, z wyjątkiem Mołdawskiej SSR, która stanowiła odrębną jednostkę administracyjną oraz gospodarczą. Decyzje dotyczące lokalizacji sił wytwórczych oraz regionalizacji kraju podejmowała władza centralna przy 
współpracy Akademii Nauk ZSRR. Ponadto wprowadzono nowy organ administracyjny - Gospłan, będący Komisją Planowania ZSRR (Ławriszczew, 1969).

Podział administracyjno-terytorialny Związku silnie nawiązywał do zasięgu, uznawanych w tamtych czasach, regionów ekonomicznych. Podział ziem ukierunkowany był na „pomyślny, planowy i proporcjonalny rozwój rozszerzonej reprodukcji socjalistycznej, zarówno w skali całego państwa, jak i w skali poszczególnych republik związkowych i regionów ekonomicznych" (Ławriszczew, 1969: 27).

\section{Kapitał zagraniczny a polityka inwestycyjna Związku Radzieckiego}

Specyfika nowego systemu politycznego, polegającego na centralizacji władzy oraz ingerencji w praktycznie każdą sferę funkcjonowania państwa i życia jego mieszkańców, wiązała się również z wprowadzeniem radykalnych zmian w jego polityce zagranicznej. Izolacjonizm i chęć zapewnienia sobie niezależności ekonomicznej doprowadziły do wdrożenia przez Moskwę monopolu państwowego w handlu zagranicznym. Ponadto sukcesywnie wypierano wpływ na rynek radziecki obcego kapitału. W ramach planowania socjalistycznego rozwoju władze stworzyły tzw. uspołeczniony handel wewnętrzny, w którym partnerami były wszystkie republiki związkowe oraz szczegółowe projekty inwestycyjne. Próba utworzenia samowystarczalnego mocarstwa, z uwagi na płytkość rynku krajowego, wymagała wynalezienia nowych powiązań i kontaktów gospodarczych. Cechą charakterystyczną ZSRR był jego nieznaczny udział w globalnych przepływach środków w ramach handlu zagranicznego. Elementem aktywizującym tę sferę funkcjonowania państwa było z pewnością utworzenie w 1949 roku Rady Wzajemnej Pomocy Gospodarczej (RWPG), wykształcenie się nowego rynku, a - co za tym idzie - nowych możliwości inwestycyjnych dla państw bloku wschodniego. Istnienie rynku socjalistycznego połączyło kraje realizujące zbieżne cele i założenia polityczne, umożliwiało wymianę myśli technologicznej oraz pomoc ekonomiczną i techniczną. ZSRR, w ramach pogłębiania kontaktów gospodarczych, wprowadziło tzw. inwestycyjne

Ryc. 1. Handel zagraniczny ZSRR w latach 1946-1973

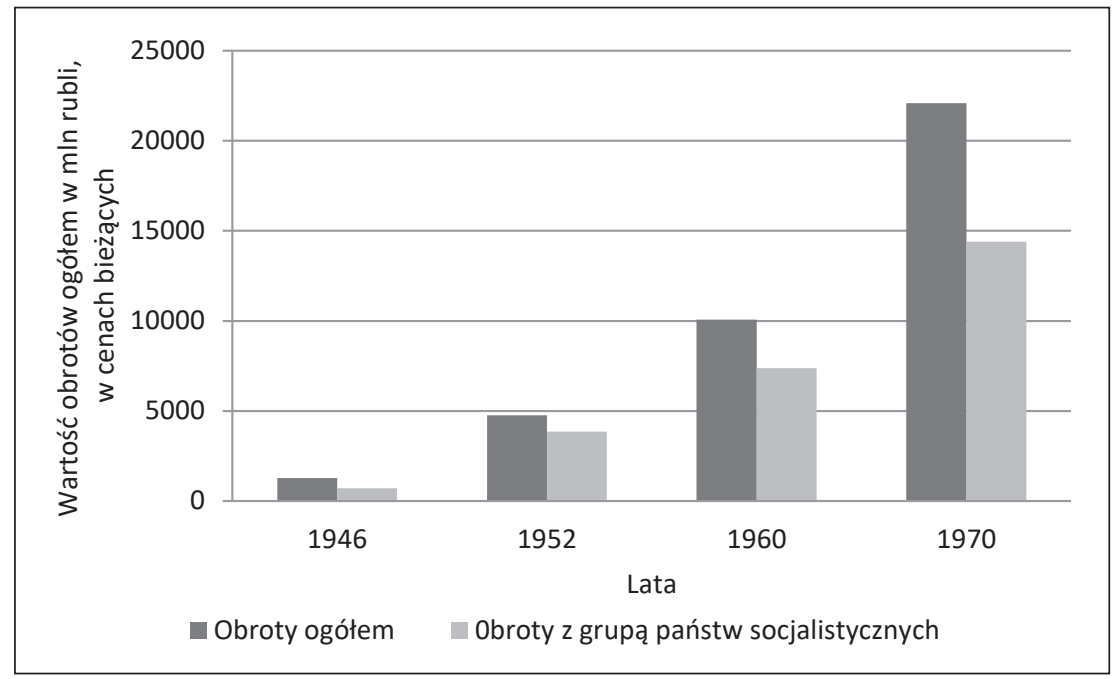

Źródło: opracowanie własne na podstawie Rychłowski (1976) 
dostawy radzieckie. Powyższe czynniki w znacznym stopniu zdynamizowały handel zagraniczny Związku Radzieckiego (ryc. 1). Nowe kierunki przepływu środków finansowych i dóbr, w ramach państw wyznających tą samą ideologię i politykę gospodarowania, pozwoliły zachować, zdaniem socjalistów, niezależność rynku radzieckiego, pozbawionego imperialistycznego, wrogiego kapitału (Szeliga, 1967; Rychłowski, 1976).

\section{Upadek Związku Radzieckiego}

Proces rozpadu Związku Radzieckiego, zakończony zawarciem w grudniu 1991 roku układu białowieskiego, zapoczątkował okres transformacji systemowych byłych republik związkowych. Moment ten można uznać za kluczową determinantę przemian w strukturze przepływów finansowych oraz kierunków i siły powiązań gospodarczych, występujących pomiędzy państwami wcześniej wchodzącymi w skład ZSRR. W wyniku upadku powyższego tworu państwowego powstało 15 niepodległych krajów (tab. 1).

Tab. 1. Państwa powstałe w wyniku rozpadu Związku Radzieckiego

\begin{tabular}{|l|c|c|}
\hline \multicolumn{1}{|c|}{ Państwo } & Liczba ludności (mln) & Powierzchnia ogółem $\left(\right.$ tys. km ${ }^{2}$ ) \\
\hline Armenia & 2,92 & 29,7 \\
\hline Azerbejdżan & 9,76 & 207,6 \\
\hline Białoruś & 9,51 & 45,2 \\
\hline Estonia & 1,32 & 69,7 \\
\hline Gruzja & 3,72 & 2724,9 \\
\hline Kazachstan & 17,80 & 199,9 \\
\hline Kirgistan & 6,08 & 64,6 \\
\hline Łotwa & 1,96 & 65,3 \\
\hline Litwa & 2,87 & 33,8 \\
\hline Mołdawia & 3,55 & 17098,2 \\
\hline Federacja Rosyjska & 144,34 & 144,1 \\
\hline Tadżykistan & 8,73 & 488,1 \\
\hline Turkmenistan & 5,66 & 603,5 \\
\hline Ukraina & 45,00 & 447,4 \\
\hline Uzbekistan & 31,85 & \\
\hline
\end{tabular}

Źródło: opracowanie własne na podstawie danych Central Intelligence Agency (2017, 15 sierpnia) i Banku Światowego $(2017,15$ sierpnia)

\section{BEZPOŚREDNIE INWESTYCJE ZAGRANICZNE W KRAJACH POSTRADZIECKICH}

W skład grupy postradzieckiej wchodzą kraje, które na początku lat dziewięćdziesiątych XX wieku stanęły przed wyzwaniem transformacji systemowej. Upadek żelaznej kurtyny otworzył im nowe możliwości, stał się szansą na zmniejszenie dysproporcji ekonomicznych, rozwój społeczno-gospodarczy oraz stopniowe przybliżanie się standardami do prężnie funkcjonujących gospodarek zachodnich. Na obecnie istniejące powiązania gospodarcze tych państw z pewnością w pierwszej kolejności wpływają opisane we wcześniejszym rozdziale uwarunkowania historyczne, w tym siedemdziesięcioletnia wspólnota gospodarcza oparta na przynależności do jednego tworu państwowego, jakim był Związek Radziecki. 
W raporcie przygotowanym w 1998 roku przez Konferencję Narodów Zjednoczonych ds. Handlu i Rozwoju wyróżniono trzy główne grupy determinant, wpływających na wielkość napływu inwestycji do kraju goszczącego: determinanty polityczne, ekonomiczne oraz tzw. udogodnienia dla biznesu. Z uwagi na specyfikę obszaru postradzieckiego kluczowymi czynnikami, w bezpośredni sposób wpływającymi na kierunki oraz wielkość przepływu bezpośrednich inwestycji zagranicznych, są: 1) stabilność polityczna, wyrażona m.in. możliwością i chęcią wstąpienia do Unii Europejskiej, przynależnością do międzynarodowych organizacji gospodarczych, przygotowaniem przejrzystych ram prawnych oraz niskim poziomem ryzyka inwestycyjnego, 2) stan procesu transformacji systemowej, 3) jakość otoczenia biznesu, w tym stosowanie bodźców inwestycyjnych czy usprawnienie administracji, np. w zakresie lokalizacji przedsiębiorstw przez zagranicznych inwestorów (Bojar, 2001; Michalik, 2010).

Analiza przepływów finansowych pochodzących z bezpośrednich inwestycji zagranicznych jest w przypadku państw postradzieckich tematem ważnym, ponieważ na jej podstawie wykazać można znaczenie tych krajów na arenie międzynarodowej. Najważniejsze, w tym przypadku, wydaje się jednak odniesienie danych statystycznych do aktualnej sytuacji geopolitycznej oraz realnego układu sił, w istotny sposób wpływających na bezpieczeństwo, rozwój oraz wiarygodność byłych republik ZSRR na arenie międzynarodowej.

Badanie powiązań gospodarczych występujących obecnie pomiędzy republikami związkowymi autorka rozpoczęła od analizy przepływów i odpływów (inflows i outflows) bezpośrednich inwestycji zagranicznych per capita w 2014 roku. Na podstawie dostępnych danych statystycznych, opublikowanych przez Międzynarodowy Fundusz Walutowy, zauważyć można, iż w grupie postradzieckiej do państw inwestujących najwyższą wartość środków finansowych zaliczyć można największy kraj w regionie - Federację Rosyjską, oraz położony w południowej części Kaukazu Azerbejdżan - charakteryzujący się silną pozycją z uwagi na posiadane strategiczne złóża naturalne. W odniesieniu do odpływów (outflows) najbardziej popularnymi lokalizacjami (biorąc pod uwagę ogólną wartość inwestycji tego typu) były Azerbejdżan, Kazachstan oraz Gruzja.

Do wykazania, czy w przypadku państw postradzieckich można mówić o tendencjach wskazujących na reorientację powiązań gospodarczych oraz otwarcie na nowe rynki, konieczne jest odwołanie się do danych dotyczących struktury geograficznej bezpośrednich inwestycji zagranicznych, w tym do przepływów finansowych występujących pomiędzy badanymi jednostkami.

Zgodnie z powyższym, kolejnym analizowanym w badaniu wskaźnikiem były wartości dotyczące udziału BIZ, wprowadzanych przez przedsiębiorstwa- matki pochodzące z obszaru postradzieckiego w ich zagraniczne filie umiejscowione na obszarze byłych republik związkowych. Na podstawie statystyk dotyczących „wewnętrznych” zasobów (inward position/stock) stwierdzić można, iż do grupy krajów najbardziej uzależnionych od wpływu kapitału pochodzącego z analizowanych jednostek zaliczają się: Białoruś (ponad 60\% udziału w ogólnej strukturze zasobów BIZ) oraz Armenia (około 40\%) (tab. 2). Najmniej związanymi z obszarem postradzieckim, pod względem wielkości tego typu inwestycji, są Kazachstan (2,7\%) oraz Federacja Rosyjska (0,6\%). Dostępne dane statystyczne jednoznacznie wskazują, iż największym partnerem inwestycyjnym byłych republik związkowych jest Rosja, zależność ta nie jest jednak obustronna. 
Tab. 2. Udział procentowy inwestycji z państw postradzieckich w ogólnej wielkości „wewnętrznych” zasobów BIZ tych państw w 2014 roku (inward)

\begin{tabular}{|l|r|}
\hline \multicolumn{1}{|c|}{ Kraj } & $\%$ \\
\hline Armenia & 40,1 \\
\hline Azerbejdżan & 7,0 \\
\hline Białoruś & 60,5 \\
\hline Gruzja & 14,9 \\
\hline Estonia & 11,9 \\
\hline Litwa & 9,9 \\
\hline Łotwa & 16,5 \\
\hline Mołdawia & 28,0 \\
\hline Kazachstan & 2,7 \\
\hline Kirgistan & 14,4 \\
\hline Ukraina & 8,2 \\
\hline Rosja & 0,6 \\
\hline
\end{tabular}

Źródło: opracowanie własne na podstawie danych pochodzących z bazy Coordinated Direct Investment Survey IMF (2016, 25 grudnia)

Autorka odniosła się też do wskaźnika prezentującego procentowy udział inwestycji pochodzących z państw obszaru postradzieckiego do ogólnej wielkości „zewnętrznych" zasobów tych państw (outward position/stock). Na wstępnie należy jednak zaznaczyć, iż fragmentaryzacja danych udostępnionych przez Międzynarodowy Fundusz Walutowy, przy jednoczesnym braku możliwości porównania wykorzystanych w analizie statystyk z informacjami publikowanymi przez inne organizacje międzynarodowe czy analizowane państwa (liczne rozbieżności), spowodowały, iż niemożliwe było w tym przypadku odniesienie się do sytuacji wszystkich badanych jednostek.

Przedstawione dane (tab. 3) potwierdzają silne powiązania gospodarcze występujące pomiędzy Białorusią a byłymi republikami związkowymi. Warto jednak dodać, iż w szczególności stwierdzenie to odnosi się do Federacji Rosyjskiej, jej największego partnera politycznego i gospodarczego. Interesujący wydaje się również udział procentowy BIZ niewielkiego Kirgistanu, z którego 100\% środków finansowych w postaci inwestycji zostało zlokalizowane w sąsiadującym z nim Tadżykistanie. Dane dotyczące Kazachstanu i Rosji potwierdzają ich istotną, biorąc pod uwagę inne państwa wchodzące w skład grupy, niezależność gospodarczą w odniesieniu do innych byłych republik ZSRR. Wartość zewnętrznych zasobów Rosji, w odwołaniu do wcześniej analizowanego wskaźnika inward position, obrazuje, iż pomimo jej ważnej roli w przepływach inwestycyjnych grupy de facto inwestuje w nią niewielki (około 5\%) odsetek ogólnej wartości środków inwestycyjnych.

Dane dotyczące głównych partnerów inwestycyjnych państw postradzieckich w 2014 roku, publikowane w postaci rankingów, potwierdzają, iż w przypadku badanych jednostek mówić można o częściowej reorientacji kierunków powiązań gospodarczych (tab. 4). Wśród byłych republik pojawiają się nowe kierunki przepływów BIZ, częściowo państwa te przyjmują globalne tendencje, np. w odniesieniu do wzrostu znaczenia inwestycji pochodzących z wysoko rozwiniętych państw Triady (Stanów Zjednoczonych, Kanady czy Niemiec). Ważna jest ponadto lokalizacja, co potwierdzają częste obustronne inwestycje państw sąsiadujących. 
Tab. 3. Udział procentowy inwestycji z państw postradzieckich w ogólnej wielkości „zewnętrznych” zasobów BIZ tych państw w 2014 roku (outward)

\begin{tabular}{|l|r|}
\hline \multicolumn{1}{|c|}{ Kraj } & $\%$ \\
\hline Azerbejdżan & 30,0 \\
\hline Białoruś & 91,0 \\
\hline Estonia & 50,8 \\
\hline Litwa & 28,2 \\
\hline Łotwa & 45,1 \\
\hline Kazachstan & 5,6 \\
\hline Kirgistan & 100,0 \\
\hline Rosja & 4,9 \\
\hline
\end{tabular}

Źródło: opracowanie własne na podstawie danych pochodzących z bazy Coordinated Direct Investment Survey IMF (2016, 25 grudnia)

Tab. 4. Główni partnerzy inwestycyjni państw postradzieckich w 2014 roku

\begin{tabular}{|l|l|l|}
\hline \multicolumn{1}{|c|}{ Kraj } & \multicolumn{1}{|c|}{$\begin{array}{c}\text { Państwo inwestujące } \\
\text { (inward) }\end{array}$} & \multicolumn{1}{c|}{$\begin{array}{c}\text { Państwo goszczące inwestycje } \\
\text { (outward) }\end{array}$} \\
\hline Armenia & Federacja Rosyjska & totwa \\
\hline Azerbejdżan & Turcja & Turcja \\
\hline Białoruś & Federacja Rosyjska & Federacja Rosyjska \\
\hline Estonia & Szwecja & Cypr \\
\hline Gruzja & Stany Zjednoczone & dane niedostępne \\
\hline Kazachstan & Holandia & Holandia \\
\hline Kirgistan & Kanada & Tadżykistan \\
\hline Łotwa & Szwecja & Litwa \\
\hline Litwa & Szwecja & Holandia \\
\hline Mołdawia & Federacja Rosyjska & dane niedostępne \\
\hline Turkmenistan & dane niedostępne & dane niedostępne \\
\hline Tadżykistan & dane niedostępne & dane niedostępne \\
\hline Ukraina & Niemcy & dane niedostępne \\
\hline Federacja Rosyjska & Cypr & Cypr \\
\hline
\end{tabular}

Źródło: opracowanie własne na podstawie danych pochodzących z bazy Coordinated Direct Investment Survey IMF (2016, 25 grudnia)

Zainteresowanie wzbudzają z pewnością silne powiązania występujące pomiędzy Federacją Rosyjską oraz niewielkim Cyprem. Powyższe zjawisko tłumaczyć należy próbą uzyskania przez inwestorów rosyjskich ulg podatkowych. Ulokowany, de facto rosyjski, kapitał w przedsiębiorstwo zarejestrowane na wyspie powraca do Federacji formalnie w postaci środków cypryjskich i uznawane jest za bezpośrednią inwestycję partnera zagranicznego (Karaszewski, 2004).

Wpływ na kierunki inwestycji państw postradzieckich mogą mieć ponadto kwestie kulturowe, strategiczne oraz rozkład sił i stref wpływów potęg gospodarczych regionu, o czym świadczyć mogą relacje występujące pomiędzy Turcją i Azerbejdżanem czy Federacją Rosyjską oraz znajdującymi się w jej strefie wpływów: Armenią, Białorusią czy Mołdawią.

Na silne powiązania gospodarcze Turcji i Azerbejdżanu wpływa przede wszystkim spójność interesów (rozwój i bezpieczeństwo sektora energetycznego tych państw) 
oraz bliskość kulturowa. Azerbejdżan jako jedyny kraj na Kaukazie Południowym, w którym religią dominującą jest islam, od odzyskania niepodległości w 1991 roku uznawany jest za najważniejszego sojusznika Turcji w regionie (Zasztowt, 2008).

Federację Rosyjską z Armenią i Białorusią wiąże przede wszystkim partnerstwo we Wspólnocie Niepodległych Państw oraz powołanej w 2014 roku Euroazjatyckiej Wspólnocie Gospodarczej, będącej przeciwwagą dla Unii Europejskiej. Istotne wsparcie Federacji, nie tylko w kwestiach ekonomicznych, ale również politycznych, wynika z położenia geopolitycznego tych państw.

Białoruś uznawana jest za głównego partnera Rosji w dążeniach do integracji i odbudowy powiązań na obszarze postradzieckim. Jej strategiczne usytuowanie na styku Europy Wschodniej i Unii Europejskiej powoduje, iż jest szczególnie ważna dla Rosji ze względów bezpieczeństwa terytorialnego oraz gospodarki (tranzyt surowców na Zachód oraz do obwodu kaliningradzkiego). Większość rosyjskich inwestycji na obszarze Białorusi najczęściej wiąże się z prywatyzacją przedsiębiorstw państwowych (głównie w branży energetycznej, telekomunikacyjnej, ale także zbrojeniowej). Natomiast budowa ścisłych relacji gospodarczych i politycznych z Armenią zapewnia Rosji obecność (np. poprzez lokalizację baz wojskowych) i względną kontrolę w regionie Kaukazu Południowego ${ }^{2}$. Do głównych narzędzi stosowanych przez Rosję w procesie stopniowego uzależniania od siebie Armenii oraz Białorusi należą np. preferencyjne kredyty czy obniżki cen za surowce energetyczne (Wierzbowska-Miazga, 2013).

Odmienną sytuacją charakteryzuje się Mołdawia, która po upadku Związku Radzieckiego i ogłoszeniu niepodległości skierowała cele swojej polityki zagranicznej w stronę integracji z UE (w 2014 roku podpisała z nią umowę stowarzyszeniową). Próba reorientacji kierunków powiązań politycznych i gospodarczych spotkała się jednak ze sprzeciwem ze strony Federacji Rosyjskiej, która, chcąc wpłynąć na politykę tego państwa, wprowadziła i stopniowo rozszerzała embargo na mołdawskie produkty. Pojawienie się alternatywy dla UE w postaci Unii Celnej, obawa przed wydaleniem mołdawskich emigrantów z Rosji (Federacja jest głównych kierunkiem wyjazdów zarobkowych Mołdawian) i utrzymaniem sankcji gospodarczych blokujących rozwój gospodarczy oraz wielkość rosyjskich bezpośrednich inwestycji zagranicznych w mołdawską gospodarkę doprowadziły do podziału społeczeństwa, posiadającego odmienne poglądy dotyczące przyszłego umiejscowienia państwa na geopolitycznej mapie Europy (Całus, $2014 ; 2016)^{3}$.

Na uwagę zasługuje fakt, iż głównym partnerem inwestycyjnym Gruzji w 2014 roku były Stany Zjednoczone. Zjawisko to może potwierdzać, iż pomimo trudnej sytuacji wewnętrznej (część obszaru znajduje się poza jurysdykcją władz kraju), państwo sukcesywnie uniezależnia się od swojego północnego sąsiada (np. rezygnując z członkowska w WNP), z powodzeniem niweluje negatywne skutki transformacji systemowej oraz realizuje założenia otwartości oraz integracji z Zachodem.

${ }^{2} \mathrm{O}$ wpływie Rosji na ormiańską politykę świadczyć może fakt, iż kraj ten jednoznacznie poparł działania Rosji w stosunku do Ukrainy. Badacze zajmujący się relacjami występującymi pomiędzy Federacją i Armenią wskazują ponadto na wewnętrzne negatywne skutki zbliżenia gospodarczego tych państw, np.: obniżenie znaczenia opozycji czy ugruntowanie pozycji oligarchicznego systemu funkcjonowania państwa (Ananicz, 2014).

${ }^{3}$ K. Całus (2016) w publikacji Państwo niedokończone. 25 mołdawskiej niepodległości wskazuje, iż w 2016 roku dążenia do integracji z Unią Europejską poparło 43\% społeczeństwa, natomiast z Unią Euroazjatycką 44\%. 


\section{WNIOSKI}

Na podstawie danych statystycznych dotyczących wielkości i struktury geograficznej bezpośrednich inwestycji zagranicznych stwierdzono, iż w przypadku tylko części państw postradzieckich mówić można o rzeczywistym otwarciu swoich rynków oraz o obraniu nowych kierunków powiązań (ryc. 2).

Gospodarki analizowanych krajów należy de facto podzielić na dwie grupy: pierwszą, otwierającą się na inwestycje pochodzące z Zachodu, oraz drugą, utrzymującą silne powiązania z obszarem postradzieckim, precyzyjniej ujmując, z Federacją Rosyjską. Powyższa integracja odnosi się nie tylko do kwestii ekonomicznych, ale również do polityki, zasięgu strefy wpływów Rosji. Tendencja ta niewątpliwie pogłębia stabilne i powstałe w przeszłości relacje. Należy jednak podkreślić, iż wiąże się to również z wysokim stopniem uzależnienia tych państw od jednego partnera, co rzutuje na wybory polityczne ich władz.

Badanie pozwoliło również na wyodrębnienie cech charakteryzujących obecnie występujące powiązania gospodarcze na obszarze postradzieckim, do których zaliczyć można:

- istotny wpływ na rynki postradzieckie ma Federacja Rosyjska, często będąca głównym, lub jednym z głównych, partnerem inwestycyjnym, np. Armenii czy Białorusi,

- biorąc pod uwagę ogół analizowanych państw, zauważono zmniejszające się znaczenie występujących pomiędzy nimi powiązań na rzecz przyjmowania globalnych tendencji. Dochodzi więc do sukcesywnej reorientacji powiązań,

- bliskość geograficzna (częste sąsiedztwo partnerów inwestycyjnych) wpływa na decyzje dotyczące lokalizacji inwestycji,

- kierunki i wielkość przepływów BIZ często mają konotacje z występowaniem bliskości politycznej czy kulturowej partnerów.

Ryc. 2. Podział państw postradzieckich ze względu na charakter ich powiązań gospodarczych
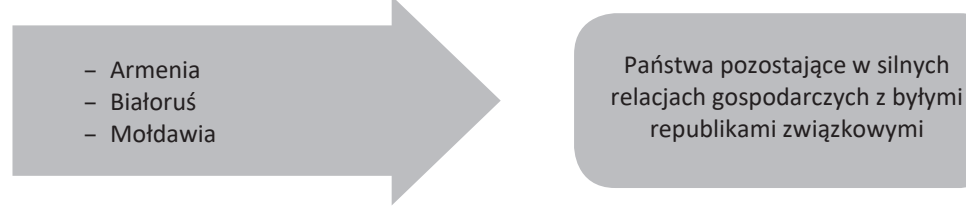

- Azerbejdżan

- Estonia

- Federacja Rosyjska

- Gruzja

- Kazachstan

- Kirgistan

Państwa reorientujące swoje powiązania gospodarcze

- Litwa

- Łotwa

- Ukraina

Źródło: opracowanie własne na podstawie danych pochodzących z bazy Coordinated Direct Investment Survey IMF (2016, 25 grudnia) 


\section{Literatura \\ References}

Ananicz, S., (2014).Armenia na drodze do Unii Celnej (i większego uzależnienia od Rosji). Pozyskano z: https://www.osw.waw.pl/pl/publikacje/analizy/2014-04-16/armenia-na-drodze-do-unii-celnej-i-wiekszego-uzaleznienia-od-rosji

Bank Światowy (2017,15 sierpnia). Pozyskano z http://www.worldbank.org/

Bojar, E. (2001). Bezpośrednie inwestycje zagraniczne w obszarach słabo rozwiniętych. Warszawa: Wydawnictwo Naukowe PWN.

Całus, K., (2014). Rosyjskie sankcje wobec Mołdawii. Niewielkie efekty, spory potencjał. Komentarze OSW (152). Warszawa: Ośrodek Studiów Wschodnich im. Marka Karpia. Pozyskano z https://www.osw.waw.pl/sites/default/files/komentarze_152.pdf

Całus, K. (2016). Państwo niedokończone. 25 lat mołdawskiej państwowości. Prace OSW (59). Warszawa: Ośrodek Studiów Wschodnich im. Marka Karpia. Pozyskano z https://www. osw.waw.pl/sites/default/files/prace_59_pl_25_lat_moldawskiej_net.pdf

Central Intelligence Agency (2017, 15 sierpnia). Pozyskano z https://www.cia.gov/library/publications/the-world-factbook/

Cieślik, A. (2005). Geografia inwestycji zagranicznych. Przyczyny i skutki lokalizacji spółek z udziałem kapitału zagranicznego w Polsce. Warszawa: Wydawnictwo Uniwersytetu Warszawskiego.

Coordinated Direct Investment Survey IMF (2016, 25 grudnia). Pozyskano z http://data.imf.org/?sk=40313609-F037-48C1-84B1-E1F1CE54D6D5\&sId=1390030109571

Domański, B. (2001). Kapitał zagraniczny w przemyśle Polski. Kraków: Instytut Geografii i Gospodarki Przestrzennej Uniwersytetu Jagiellońskiego.

Karaszewski, W. (2004). Bezpośrednie inwestycje zagraniczne. Polska na tle świata. Toruń: Wydawnictwo Dom Organizatora.

Ławriszczew, A. (1969). Geografia ekonomiczna ZSRR. Warszawa: Państwowe Wydawnictwo Ekonomiczne.

Maryański, A. (1987). Geografia ekonomiczna Zwiq̨zku Radzieckiego. Warszawa: Państwowe Wydawnictwo Ekonomiczne.

Michalik A., (2010). Determinanty lokalizacji bezpośrednich inwestycji zagranicznych. W: M. Maciejewski, S. Wydmus (red.). Bezpośrednie inwestycje zagraniczne jako czynnik konkurencyjności handlu zagranicznego. Kraków: Fundacja Uniwersytetu Ekonomicznego w Krakowie.

Michałków, I. (2003). Bezpośrednie inwestycje zagraniczne w Polsce w dobie globalizacji. Warszawa: Wyższa Szkoła Ekonomiczna.

Olifirowicz, M., Wasilik- Dusińska, A. (red.) (2002). Bezpośrednie inwestycje zagraniczne na świecie i w Polsce: tendencje, determinanty i wpływ na gospodarkę. Warszawa: Ministerstwo Gospodarki, UNCTAD.

Przygodzki, Z. (2007). Zewnętrzne uwarunkowania konkurencyjności regionów. W: J. Chądzyński, A. Nowakowska, Z. Przygodzki (red.). Region i jego rozwój w warunkach globalizacji. Warszawa: Wydawnictwo CeDeWu, 11-32.

Rychłowski, B. (red.) (1976). Kraj dwóch kontynentów. Warszawa: Krajowa Agencja Wydawnicza.

Szeliga, Z. (1967). Gospodarka ZSRR na tle gospodarki świata. Warszawa: Państwowe Wydawnictwo Ekonomiczne.

Wierzbowska-Miazga, A. (2013). Wsparcie drogą do podporządkowania. Punkt Widzenia (34). Warszawa: Ośrodek Studiów Wschodnich im. Marka Karpia. Pozyskano z https://www. osw.waw.pl/sites/default/files/pw_34_bialorus_pl_net.pdf.

Zasztowt, K. (2008). Stosunki Republiki Turcji z państwami Kaukazu Południowego. W: K. Iwańczuk, T. Kapuściński (red.). Region Kaukazu w stosunkach międzynarodowych. Lublin: Wydawnictwo Uniwersytetu Marii Curie-Skłodowskiej.

Zorska, A. (2000). Ku globalizacji? Przemiany w korporacjach transnarodowych i gospodarce światowej. Warszawa: Wydawnictwo Naukowe PWN.

Zorska, A. (2007). Korporacje transnarodowe. Przemiany, oddziaływania, wyzwania. Warszawa: Polskie Wydawnictwo Ekonomiczne. 
Julia Kaczmarek-Khubnaia, mgr., doktorantka w Instytucie Geografii Społeczno-Ekonomicznej Gospodarki Przestrzennej, Wydział Nauk Geograficznych i Geologicznych, Uniwersytet im. Adama Mickiewicza w Poznaniu. Podejmowana przez nią tematyka badawcza obejmuje zagadnienia z zakresu geografii społeczno-ekonomicznej obszaru postradzieckiego. Prowadzone przez nią analizy dotyczą przede wszystkim podziałów regionalnych Gruzji, ich uwarunkowań oraz rozwoju poszczególnych jednostek podziału terytorialnego.

Julia Kaczmarek-Khubnaia, M.Sc., Ph.D. student in the Institute of Socio-Economic Geography and Spatial Management, Faculty of Geographical and Geological Sciences, Adam Mickiewicz University in Poznan. In her research, she focuses mainly on issues concerning socio-economic geography of the post-Soviet region. In her work she concentrates predominately on regional divisions of Georgia. More specifically, she analyses their underlying determinants and development level of different territorial units.

\section{Adres/address:}

Uniwersytet im. Adama Mickiewicza w Poznaniu

Wydział Nauk Geograficznych i Geologicznych

Instytut Geografii Społeczno-Ekonomicznej i Gospodarki Przestrzennej

Zakład Polityki Regionalnej i Integracji Europejskiej

ul. Bogumiła Krygowskiego 10, 61-680 Poznań, Polska

e-mail: khubnaia@amu.edu.pl

Projekt został sfinansowany ze środków Narodowego Centrum Nauki przyznanych na podstawie decyzji numer DEC-2011/01/B/HS4/03234. 